\title{
SKALA WYDOLNOŚCI OPIEKUŃCZEJ (SWO) - WSTĘPNA CHARAKTERYSTYKA PSYCHOMETRYCZNA
}

\author{
SCALE EFFICIENCY OF CARE (SEC) - INITIAL PSYCHOMETRIC CHARACTERISTICS \\ Anna Kurowska ${ }^{1, a}$, Maria Kózka ${ }^{2, b}$, Anna Majda ${ }^{1, c}$, Agata Wojcieszek $^{3, d}$ \\ ${ }^{1}$ Pracownia Teorii i Podstaw Pielęgniarstwa, Wydział Nauk o Zdrowiu, Uniwersytet Jagielloński, Collegium Medicum w Krakowie \\ ${ }^{2}$ Wydział Nauk o Zdrowiu, Uniwersytet Jagielloński, Collegium Medicum w Krakowie \\ ${ }^{3}$ Uczestnik studiów doktoranckich na Wydziale Nauk o Zdrowiu Uniwersytetu Jagiellońskiego, Collegium Medicum w Krakowie
}

${ }^{\text {a }}$ https://orcid.org/0000-0002-2937-5346

${ }^{b}$ https://orcid.org/0000-0002-5165-6929

${ }^{c}$ https://orcid.org/0000-0003-3632-1319

${ }^{\mathrm{d}}$ https://orcid.org/0000-0002-7997-7580

DOI: https://doi.org/10.20883/pielpol.2020.4

\section{STRESZCZENIE}

Wstęp. Rodzina pełni wiele kluczowych funkcji w życiu człowieka m.in. funkcję opiekuńczo-zabezpieczającą, którą należy rozumieć jako sprawowanie opieki nad niesamodzielnymi i niezdolnymi do samopielęgnacji członkami rodziny. Prac podejmujących problematykę wydolności opiekuńczej rodziców wychowujących dzieci z zaburzeniami rozwojowymi i dzieci zdrowe jest niewiele. Istnieje konieczność eksploracji tego zagadnienia przy pomocy wystandaryzowanych narzędzi badawczych o zadawalających właściwościach psychometrycznych, oceniających złożony proces opieki nad dzieckiem.

Cel. Celem pracy było określenie psychometrycznych właściwości autorskiego narzędzia badawczego służącego do oceny wydolności opiekuńczej rodziców.

Materiał i metody. Badaniem o charakterze przekrojowym, objęto rodziców wychowujących dzieci z niepełnosprawnością (grupa badana - 243 osób) oraz rodziców dzieci bez zaburzeń rozwojowych (grupa porównawcza - 264 osób). W badaniu wykorzystano autorską Skalę Wydolności Opiekuńczej (SWO).

Wyniki. Wyniki uzyskane w SWO różniły się między grupami. Wyliczony dla obydwu grup wskaźnik Alfa-Cronbacha potwierdził rzetelność autorskiego narzędzia badawczego. W ramach szacowania trafności kryterialnej uzyskano korelację SWO z GSES, skalą o podobnej koncepcji teoretycznej. Trafność SWO zweryfikowano też w konfirmacyjnej analizie czynnikowej (CFA).

Wnioski. SWO cechują zadowalające właściwości psychometryczne - rzetelność i trafność. Skala ta może dostarczyć wielu cennych informacji o poziomie wydolności opiekuńczej rodziców. Uzyskane rezultaty przemawiają za stosowaniem SWO w badaniach naukowych i jej dalszym doskonaleniem.

SŁOWA KLUCZOWE: opieka, wydolność, rodzice, dzieci, niepełnosprawność.

\begin{abstract}
Introduction. The family performs many key functions in human life, including a guardian-protective function, which should be defined as taking care of dependent and unable to self-care family members. There are not many papers on the issues of care efficiency of parents raising children with developmental disorders and healthy children. There is a need to explore this issue using standardized research tools with satisfactory psychometric properties that evaluate the complex process of childcare.

Aim. The aim of the study was to evaluate the psychometric properties of an original research tool used to assess the care efficiency of parents.

Material and methods. In the cross-sectional study participated parents raising children with disabilities (study group -243 people) and parents of children without developmental disorders (comparative group - 264 people). During the study the original Scale Efficiency of Care (SEC) was used.

Results. The results obtained in the SEC differed between the groups. The Cronbach's alpha coefficient in both groups confirmed the reliability of the author's research tool. During the estimation of criterion validity, a correlation between the SEC and GSES, a scale with a similar theoretical concept was obtained. The validity of the SEC was also verified in the confirmatory factor analysis (CFA).

Conclusions. The SEC is characterized by satisfactory psychometric properties - reliability and validity. This scale can provide a lot of valuable information about the level of care efficiency of parents. The obtained results support the use of the SEC in scientific research and its further improvement.
\end{abstract}

KEYWORDS: care, efficiency, parents, children, disability. 


\section{Wprowadzenie}

Zdrowie jednostki ściśle związane jest z właściwym funkcjonowaniem wspólnoty, jaką jest rodzina. Pełni ona wiele kluczowych funkcji w życiu człowieka. Umożliwia rozwiązywanie jego problemów wynikających, np. z dysfunkcji na płaszczyźnie biologicznej, psychicznej czy społecznej, gdyż w tych sferach należy rozpatrywać pojęcie zdrowia lub jego brak [1]. Środowisko rodzinne może skutecznie oddziaływać na efekty zdrowotne uzyskiwane przez jednostkę, a tym samym znacząco usprawniać proces leczenia i pielęgnacji [2].

We właściwym funkcjonowaniu rodziny ogromne znaczenie odgrywa pełniona przez nią funkcja opiekuńczo-zabezpieczająca. Obejmuje ona, m.in. pielęgnację i opiekę dostarczaną tym członkom rodziny, którzy są niesamodzielni i niezdolni do samopielęgnacji - niemowlę, dziecko, osoba starsza, osoba z niepełnosprawnością. Funkcję tę należy rozumieć także, jako zapewnienie bezpieczeństwa i stabilizacji. Można to definiować jako zabezpieczenie materialne (zadowalająca sytuacja bytowa i mieszkaniowa rodziny), ale także równowagę i spójność życia rodzinnego (rodzina pełna, w której panują prawidłowe relacje między poszczególnymi członkami rodziny, właściwy podział ról, zadań i obowiązków) [3].

Zaburzenia w funkcjonowaniu rodziny spowodowane wieloma różnorodnymi czynnikami, takimi jak np.: zła sytuacja materialna (niskie dochody, brak pracy), stres, napięcie, konflikty rodzinne oraz obciążenie odczuwane przez rodziców, a także brak wsparcia otoczenia, negatywnie oddziałują na rozwój psychiczny dziecka, czyniąc je często jednostką niedostosowaną społecznie $[2,4]$.

Termin wydolności opiekuńczej, który często nazywany jest także potencjałem opiekuńczym, został upowszechniony w literaturze polskiej dzięki licznym publikacjom Z. Kawczyńskiej-Butrym. Prowadziła ona badania m.in. wśród rodzin osób z niepełnosprawnością [5]. W swoich pracach dokonała tzw. diagnozy rodzinnej opierającej się głównie na dwóch etapach. Pierwszy z nich polegał na: „określeniu obszarów zagrożeń i dysfunkcji normalnej egzystencji rodziny, a więc zagrożeń i dysfunkcji związanych z zaspokojeniem przez nią podstawowych potrzeb i potrzeb rozwoju" [6, s. 98]. Drugi natomiast odnosił się do oceny potencjału rodziny, który dostarcza danych, w jakich obszarach rodzina jest samowystarczalna, a w jakich potrzebuje stymulacji mającej na celu wzmocnienie wewnętrznych sił i przygotowanie do radzenia sobie. Właściwie przeprowadzona diagnoza rodzinna umożliwia zaplanowanie pomocy oraz określenie rodzaju i zakresu wsparcia pożądanego i oczekiwanego przez osobę z niepełnosprawnością, a także jej rodzinę [6].
Potencjał opiekuńczy rodziny to zagadnienie, które często pojawia się w odniesieniu do opiekunów osób starszych będących w wieku poprodukcyjnym. J. Hrynkiewicz stwierdził, iż w Polsce pojęcie to należy rozumieć „jako zdolność rodziny do świadczenia opieki swoim starym, niesamodzielnym i niepełnosprawnym członkom" [7, s. 12-13]. Jako przyczynę zmniejszania się potencjału opiekuńczego J. Hrynkiewicz wymienił czynniki demograficzne (np. mniejsza liczebność rodzin), ekonomiczne (np. migracja zarobkowa) i społeczne (zaburzenie relacji wśród członków rodziny) [7].

Wydolność opiekuńczo-pielęgnacyjna rodziny zależy od szeregu czynników wewnętrznych i zewnętrznych, między którymi zachodzi ciągła interakcja. Według Z. Kawczyńskiej-Butrym do czynników wewnątrz rodzinnych można zaliczyć m.in.: „poziom sprawności fizycznej i psychicznej członków rodziny” (1), „pełność i niepełność rodziny” (2), „wielodzietność” (3), „fazy życia rodziny” (4), „motywacje” (5), „dyspozycyjność członków rodziny” (6), „sytuację bytową” (7), „wiedzę i umiejętności” (8), „poziom wykształcenia dorosłych członków rodziny” (9) oraz „inne szczególne sytuacje patologia" (10) [6, 8].

Należy zaznaczyć, iż dokonując oceny potencjału opiekuńczego rodziny należy wziąć także pod uwagę czynniki zewnątrzrodzinne, czyli najbliższe otoczenie. Diagnoza czynników wewnątrz- i zewnątrzrodzinnych jest niezwykle ważna, umożliwia, bowiem wczesne zidentyfikowanie problemów „zdezorganizowanej” rodziny oraz pomoc w ich rozwiązaniu $[6,8]$.

Potencjału opiekuńczego rodziny nie należy analizować w oderwaniu od zasobów osobistych, jakimi dysponują rodzice sprawujący opiekę nad niesamodzielnymi i niezdolnymi do samopielęgnacji członkami rodziny. Jednym z istotnych zasobów, który został wspomniany w niniejszej pracy, jest poczucie własnej skuteczności, odgrywające niezwykle ważną rolę w procesie opieki i pielęgnacji. Pojęcie to zostało wprowadzone prze kanadyjskiego psychologa - Albera Bandurę. Mierzy ono ogólne przekonanie co do skuteczności radzenia sobie (ang. coping) w trudnych, problematycznych sytuacjach, co wpływa na inne osobiste zasoby jednostki, jakie uruchamiane są w celu pokonania przeszkody, przezwyciężenia stresu $[9,10]$.

Prac podejmujących problematykę wydolności opiekuńczej rodziców wychowujących dzieci z zaburzeniami rozwojowymi i dzieci zdrowe jest niewiele. Istnieje konieczność dalszej eksploracji tego zagadnienia przy pomocy właściwych narzędzi wykorzystywanych do oceny złożonego procesu opieki nad dzieckiem. Istnieje zasadność projektowania i wdrażania nowych rozwiązań, których celem będzie ocena funkcjonalności rodziny nie tylko w aspekcie opieki, ale także w innych obszarach. Autorska Skala Wydolności Opiekuńczej 
(SWO), jaką opracowali autorzy niniejszej pracy może zostać wykorzystana, jako narzędzie w innych badaniach o zbliżonej tematyce.

\section{Cel}

Głównym celem pracy było zaprezentowanie autorskiego narzędzia badawczego - Skali Wydolności Opiekuńczej (SWO) - służącego do oceny wydolności opiekuńczej rodziców wychowujących dzieci z niepełnosprawnością oraz dzieci zdrowe, a także określenie psychometrycznych właściwości opracowanej skali.

\section{Materiał i metody}

Badanie miało charakter przekrojowy, którym objęto 507 osób, w tym 243 rodziców dzieci z niepełnosprawnością (grupa badana) i 264 rodziców wychowujących dzieci zdrowe (grupa porównawcza). Zespoły Szkół Specjalnych, Specjalne Ośrodki Szkolno-Wychowawcze oraz Zespoły Szkół Ogólnokształcących zlokalizowane na terenie Krakowa stanowiły miejsce badań.

Podczas spotkań organizacyjnych respondenci zostali poinformowani, iż badanie jest dobrowolne, anonimowe i można wycofać się na każdym jego etapie bez podawania przyczyny.

Badanie zostało przeprowadzone zgodnie z zasadami Deklaracji Helsińskiej [11] po uzyskaniu pozytywnej opinii Komisji Bioetycznej Uniwersytetu Jagiellońskiego oraz pisemnej zgody dyrekcji placówek objętych badaniem. Badanie było finansowane ze środków pochodzących z dotacji celowej dla młodych naukowców oraz uczestników studiów doktoranckich do 35. roku życia (numer: K/DSC/002876).

W badaniu wykorzystano metodę szacowania, która umożliwiła zebranie danych na kilkustopniowej skali. Techniką zastosowaną w badaniu była skala szacunkowa. Cechy i zachowanie rodziców oceniane były za pomocą określonych kryteriów oceny, czyli stopni narzucających dany porządek [12]. Do analizy danych zostały wykorzystane także metody statystyczne umożliwiające opracowanie i interpretację wyników. Podczas porównywania wyników SWO grupy badanej i porównawczej wykorzystano test t-Studenta. Korelacja SWO z innym narzędziem o podobnym konstrukcie teoretycznym została zaprezentowana przy użyciu współczynnika korelacji rang Spearmana. Potwierdzająca analiza czynnikowa SWO została przeprowadzona z wykorzystaniem metody dwuwskaźnikowej Hu i Bentlera [13]. W trakcie opracowywania wyników przyjęto poziom istotności $\alpha=0,05$. Zebrany materiał badawczy opracowano przy użyciu pakietu statystycznego R 3.2.3 [14].

Opracowana Skala Wydolności Opiekuńczej (SWO) (ang. Scale Efficiency of Care; SEC) składała się z 12 twierdzeń, które dotyczyły interwencji opiekuńczo-pie- lęgnacyjnych podejmowanych zarówno przez rodziców dzieci z niepełnosprawnością, jak i rodziców dzieci zdrowych. Narzędzie zostało skonstruowane w taki sposób, aby jego treść nie naruszała dobra uczestników badania, a zawarte w nim komunikaty były czytelne i zrozumiałe dla ankietowanych. Podczas projektowania SWO użyto skali Likerta, pozwalającej zbadać opinię rodziców na temat ich potencjału opiekuńczego [15]. Respondent miał możliwość wybrania jednego z wariantów odpowiedzi, któremu przyporządkowana była określona liczba punktów: „zdecydowanie tak” - 5 pkt, „raczej tak” - 4 pkt, „nie wiem” - 3 pkt, „raczej nie” - 2 pkt, ,zdecydowanie nie" - 1 pkt. Wynik surowy otrzymany po zsumowaniu punktów z poszczególnych twierdzeń mógł mieścić się w przedziale od 12 do 60 pkt. Uzyskaną liczbę punktów przekształcono na jednostki standaryzowane. Umożliwiło to dokonanie interpretacji wyniku uwzględniającego właściwości charakteryzujące skalę stenową - wartości niskie (steny: 1, 2, 3, 4), przeciętne (steny 5 i 6), wysokie (steny: 7, 8, 9, 10) [16].

\section{Wyniki}

Po przeprowadzeniu analizy przy wykorzystaniu testu parametrycznego stwierdzono, iż wyniki Skali Wydolności Opiekuńczej (SWO) rodziców dzieci z niepełnosprawnością różniły się istotnie od wyników rodziców dzieci zdrowych $(p<0,05)$. Grupa badana uzyskała niższe wyniki SWO niż grupa porównawcza (Tabela 1).

Tabela 1. Porównanie wyników SWO w grupie rodziców dzieci z niepełnosprawnością i rodziców dzieci zdrowych

Table 1. Comparison of SEC results in the group of parents of children with disabilities and parents of healthy children

\begin{tabular}{lccc}
\hline SWO/SEC & $\begin{array}{c}\text { Rodzice dzieci z niepeł- } \\
\text { nosprawnością }(\mathrm{N}=243) / \\
\text { Parents of children with } \\
\text { disabilities }(N=243)\end{array}$ & $\begin{array}{c}\text { Rodzice dzieci zdro- } \\
\text { wych }(\mathrm{N}=264) / \\
\text { Parents of healthy } \\
\text { children }(N=264)\end{array} \quad \mathrm{p}^{*}$ & \\
\hline $\mathrm{M} \pm \mathrm{SD}$ & $48,25 \pm 6,04$ & $50,52 \pm 4,66$ & $<0,001$ \\
$\mathrm{Me}$ & 48 & 51 & \\
Kwartyle & $45-53$ & $48-53$ & \\
\hline
\end{tabular}

SWO - Skala Wydolności Opiekuńczej/Scale Efficiency of Care (SEC), M - średnia arytmetyczna/mean, SD - odchylenie standardowe/standard deviation, Me-mediana/ median, $\mathrm{p}$ - wartość prawdopodobieństwa/probability value

* test t-Studenta/Student's t-test

Źródło: opracowanie własne

Source: author's own analysis

Podczas opracowywania wyników stworzono odrębne normy stenowe dla rodziców wychowujących dzieci z niepełnosprawnością i rodziców mających zdrowe potomstwo, co spowodowane były istotnymi różnicami SWO między tymi dwoma grupami (Tabela 2). 
Tabela 2. Wydolność opiekuńcza rodziców - normy stenowe Table 2. Parents' care efficiency - sten scores

\begin{tabular}{|c|c|c|}
\hline \multirow[b]{2}{*}{$\begin{array}{l}\text { Sten/ } \\
\text { Sten } \\
\text { scores }\end{array}$} & \multicolumn{2}{|c|}{ Zakres punktów/Range of points } \\
\hline & $\begin{array}{c}\text { Rodzice dzieci } \\
\text { z niepełnosprawnością/ } \\
\text { Parents of children with } \\
\text { disabilities }\end{array}$ & $\begin{array}{l}\text { Rodzice dzieci zdrowych/ } \\
\text { Parents of healthy children }\end{array}$ \\
\hline 1 & $12-33$ & $12-38$ \\
\hline 2 & $34-38$ & $39-43$ \\
\hline 3 & $39-42$ & $44-45$ \\
\hline 4 & $43-45$ & $46-47$ \\
\hline 5 & $46-47$ & $48-50$ \\
\hline 6 & $48-51$ & $51-52$ \\
\hline 7 & $52-53$ & $53-55$ \\
\hline 8 & $54-55$ & $56-56$ \\
\hline 9 & $56-57$ & $57-58$ \\
\hline 10 & $58-60$ & $59-60$ \\
\hline
\end{tabular}

Źródło: opracowanie własne

Source: author's own analysis

Podczas analizy uzyskanego materiału badawczego założono, że im wyższy uzyskany wynik, tym wyższy poziom wydolności opiekuńczej (potencjału opiekuńczego). Narzędzie, jakim jest SWO, umożliwiło ocenę wydolność opiekuńczej rodziców, którą można było określić jako niską, przeciętną lub wysoką [16] (Tabela 3).

Tabela 3. Poziomy wydolności opiekuńczej rodziców Table 3. The levels of parents' care efficiency

\begin{tabular}{|c|c|c|}
\hline \multirow[b]{2}{*}{$\begin{array}{l}\text { Wyniki/ } \\
\text { Results }\end{array}$} & \multicolumn{2}{|c|}{ Zakres punktów/Range of points } \\
\hline & $\begin{array}{c}\text { Rodzice dzieci } \\
\text { z niepełnosprawnością/ } \\
\text { Parents of children with } \\
\text { disabilities }\end{array}$ & $\begin{array}{l}\text { Rodzice dzieci zdrowych/ } \\
\text { Parents of healthy children }\end{array}$ \\
\hline $\begin{array}{l}\text { Niskie/ } \\
\text { Low }\end{array}$ & $12-45$ & $12-47$ \\
\hline $\begin{array}{l}\text { Średnie/ } \\
\text { Medium }\end{array}$ & $46-51$ & $48-52$ \\
\hline $\begin{array}{l}\text { Wysokie/ } \\
\text { High }\end{array}$ & $52-60$ & $53-60$ \\
\hline
\end{tabular}

Źródło: opracowanie własne

Source: author's own analysis

Skalę Wydolności Opiekuńczej (SWO) badano za pomocą współczynnika Alfa Cronbacha. Poziom tego współczynnika wyniósł 0,808 (rodzice wychowujący dzieci z niepełnosprawnością) oraz 0,791 (rodzice wychowujący dzieci zdrowe). Wartości współczynnika Alfa Cronbacha były powyżej 0,7, co oznaczało, że opracowana skala jest spójna wewnętrznie. Dzięki czemu dowiedziono, że opracowana skala jest rzetelnym narzędziem badawczym.

W celu uzupełnienia analizy dokonano obliczenia współczynnika Alfa Cronbacha po usunięciu każdego z twierdzeń SWO. Uzyskane współczynniki Alfa Cronbacha były niższe niż w wersji ze wszystkimi 12 twierdzeniami. Wyjątek stanowiło jedynie twierdzenie numer 7 („Podczas pojawiania się trudności w zaspokajaniu potrzeb pielęgnacyjno-opiekuńczych mojego dziecka mogę liczyć na pomoc innych osób"), po jego usunięciu współczynnik Alfa Cronbacha dla rodziców dzieci z niepełnosprawnością wzrósł z 0,808 do 0,813 . Nie stanowiło to jednak dużej, znaczącej różnicy, dlatego postanowiono zostawić treść narzędzia w pierwotnej wersji, bez usuwania twierdzenia (Tabela 4).

Tabela 4. Alfa Cronbacha po usunięciu danego twierdzenia Table 4. Cronbach's alpha after removing a particular item

$\begin{array}{ccc} & \text { Rodzice dzieci } & \text { Rodzice } \\ \text { Twierdzenie/ltem } & \text { z niepełno- } & \text { dzieci } \\ & \text { sprawnością/ } & \text { zdrowych/ } \\ & \text { Parents of } & \text { Parents } \\ \text { children with } & \text { of healthy } \\ & \text { disabilities } & \text { children }\end{array}$

1. Szybko identyfikuję potrzeby opiekuńczo-pielęgnacyjne mojego dziecka/l quickly 0,791 0,772 identify the child's caring needs.

2. Szybko podejmuję działania mające na
celu zaspokojenie potrzeb opiekuńczo-
-pielęgnacyjnych mojego dziecka/l quickly
undertake action to satisfy my child's caring
needs.

3. Działania, jakie podejmuję w celu zaspokojenia potrzeb opiekuńczo-pielęgnacyjnych mojego dziecka są skuteczne/The actions I undertake to satisfy the caring needs of my $0,789 \quad 0,767$ child are effective.

4. Staram się samodzielnie zaspokajać potrzeby pielęgnacyjno-opiekuńcze mojego dziecka/l try to satisfy the caring needs of my child on my own.

5. Poświęcam wystarczającą liczbę godzin na działania mające na celu zaspokoić potrzeby pielęgnacyjno-opiekuńcze mojego dziecka/l devote enough time to actions which satisfy my child's caring needs.

6. Wywiązuję się ze wszystkich obowiązków rodzica-opiekuna/l fulfil my duties as 0,786 0,760 a parentguardian.

7. Podczas pojawiania się trudności w zaspokajaniu potrzeb pielęgnacyjno-opiekuńczych mojego dziecka mogę liczyć na pomoc innych osób/When some difficulties occur in satisfying child's caring needs, I can rely on other people's help.

8. Podczas pojawiania się trudności w zaspokajaniu potrzeb pielęgnacyjno-opiekuńczych mojego dziecka wiem, w których placówkach mogę uzyskać pomoc specjalistów/When some difficulties occur in satisfying child's caring needs, I know what institutions can help me.

9. Jestem wyposażony/-a w środki pielęgnacyjne i sprzęty medyczne, które ułatwiają mi zaspokajanie potrzeb opiekuńczo-pielęgnacyjnych mojego dziecka/l am equipped with medical care equipment that helps me to satisfy the caring needs of my child. 


$\begin{aligned} & \text { 10. Moja sytuacja materialna w pełni pozwala mi } \\ & \text { zaspokajać potrzeby pielegnacyjno-opiekuńcze } \\ & \text { mojego dziecka/My financial situation allows me }\end{aligned}$
to satisfy the caring needs of my child.
$\begin{aligned} & \text { 11. Moja wiedza i doświadczenie pomagają } \\ & \text { mi w zaspokajaniu potrzeb pieleggnacyjno- }\end{aligned}$
-opiekuńczych mojego dziecka/My knowled-
ge and experience allow me to satisfy
the caring needs of my child.

Źródło: opracowanie własne na podstawie artykułu: Determinants of care efficiency in a group of Polish parents raising children with different developmental disorders: a cross-sectional study

Source: author's own analysis based on the article: Determinants of care efficiency in a group of Polish parents raising children with different developmental disorders: a cross-sectional study [16].

Korelacja SWO z innym narzędziem o podobnej koncepcji teoretycznej - Skalą Uogólnionej Własnej Skuteczności (General Self-Efficacy Scale - GSES) [17] - wskazała na trafność opracowanego narzędzia. Przeprowadzona analiza statystyczna wykazała, iż wyniki SWO i GSES korelują istotnie ze sobą w obu badanych grupach $(p<0,05)$. Wykazana zależność była dodatnia, tzn. im wyższy wynik SWO, tym wyższy wynik GSES (Tabela 5).

Tabela 5. Korelacja SWO z narzędziem o podobnym konstrukcie teoretycznym

Table 5. Correlation between the SEC and a tool with a similar theoretical construction

\begin{tabular}{lcccc}
\hline Grupa/Group & $\begin{array}{c}\text { Współczynnik } \\
\text { korelacji SWO } \\
\text { i GSES/Coeffi- } \\
\text { cient of corre- } \\
\text { lation between } \\
\text { the SEC and } \\
\text { GSES* }\end{array}$ & $\begin{array}{c}\text { Kierunek } \\
\text { zależności/ } \\
\text { The direction } \\
\text { of depen- } \\
\text { dence }\end{array}$ & $\begin{array}{c}\text { Siła zależ- } \\
\text { ności/The } \\
\text { power of } \\
\text { dependence }\end{array}$ \\
\hline $\begin{array}{l}\text { Rodzice dzieci } \\
\text { z niepełnospraw- } \\
\text { nością/Parents } \\
\text { of children with } \\
\text { disabilities }\end{array}$ & 0,498 & $\mathrm{p}<0,001$ & $\begin{array}{c}\text { dodatni/po- } \\
\text { sitive }\end{array}$ & słaba/weak \\
$\begin{array}{l}\text { Rodzice dzieci } \\
\text { zdrowych/Pa- } \\
\text { rents of healthy } \\
\text { children }\end{array}$ & 0,391 & $\mathrm{p}<0,001$ & $\begin{array}{c} \\
\text { dodatni/po- } \\
\text { sitive }\end{array}$ & słaba/weak \\
\hline
\end{tabular}

SWO - Skala Wydolności Opiekuńczej/Scale Efficiency of Care (SEC), GSES Skala Uogólnionej Własnej Skuteczności/General Self-Efficacy Scale (GSES), p - wartość prawdopodobieństwa/probability value

* współczynnik korelacji rang Spearmana/Spearman's rank correlation coefficient Źródło: opracowanie własne

Source: author's own analysis

Bazując na metodzie dwuwskaźnikowej $\mathrm{Hu}$ i Bentlera [13] zgodnie, z którą model jest dobrze dopasowany, gdy: SRMR $<0,09$ i gdy zachodzi jeden z warunków: CFI > 0,96, TLI > 0,96 lub RMSEA < 0,06, stwierdzono, iż w przypadku SWO wymienione warunki nie zostały spełnione dla modeli I (zwykłych) - SRMR < 0,09, CFI < 0,96, TLI < 0,96, RMSEA > 0,06. Po przeprowadzeniu konfirmacyjnej analizy czynnikowej (CFA - Confirmatory Factor Analysis), celem zweryfikowania trafności, nie uzyskano potwierdzenia jednoczynnikowej struktury SWO, dlatego zastosowano modyfikacje wskazane przez tzw. indeksy modyfikacyjne (ang. modification indices). Sugerują one wprowadzenie korelacji pomiędzy następującymi parami itemów: 1 i 2, 5 i 12, 4 i 5, 6 i 9, 9 i 10, 5 i 6, 6 i 12, 4 i 7, 1 i 12. Pozwoliło to uzyskać pożądane wartości parametrów $(\mathrm{SRMR}<0,09$, RMSEA < 0,06) - modele II w tabeli 6 i tym samym potwierdzić nieco słabiej trafność SWO, jakkolwiek w akceptowalnym stopniu.

Tabela 6. Potwierdzająca analiza czynnikowa Table 6. Confirmatory factor analyis

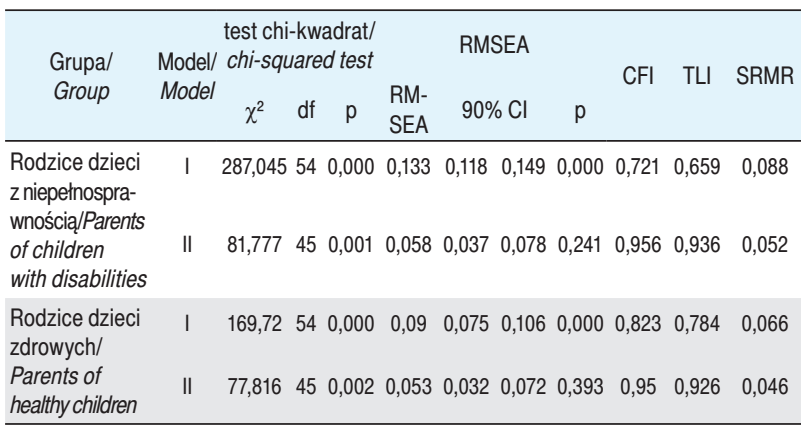

p-wartość prawdopodobieństwa/probability value, $\mathrm{Cl}$-przedziałufności/confidence interval, RMSEA - pierwiastek średniokwadratowego błędu aproksymacji/Root Mean Square Error of Approximation (RMSEA), CFI - wskaźnik dopasowania modelu/Confirmatory Fit Index (CFI), TLI - wskaźnik dopasowania modelu/TuckerLewis index (TLI), SRMR - wskaźnik dopasowania modelu/Standardized Root Mean Square Residual (SRMR)

Źródło: opracowanie własne

Source: author's own analysis

\section{Dyskusja}

Analizując dostępną literaturę, zauważono, iż prac podejmujących problematykę wydolności opiekuńczej (potencjału opiekuńczego) rodziców wychowujących swoje dzieci jest niewiele. W większości analizowane publikacje skupiają się na postawach rodziców wobec choroby dziecka oraz ocenie stanu zdrowia psychicznego i fizycznego opiekunów, a także różnorodnych czynnikach warunkujących proces opieki i pielęgnacji $[4,18,19,20,21]$. Stanowiło to motywację dla autorów niniejszej pracy do eksploracji zagadnienia wydolności opiekuńczej rodziców oraz opracowania nowatorskiego narzędzia wykorzystywanego w procesie oceny jej poziomu. 
Należy zaznaczyć, iż w badaniach własnych zagadnienie potencjału opiekuńczego nie zostało odniesione do rodzin sprawujących opiekę nad osobą starszą, jak często można to zaobserwować w innych publikacjach [22, 23, 24], lecz rodzin $z$ dzieckiem zdrowym oraz dzieckiem, u którego występują zaburzenia rozwoju, np.: upośledzenie intelektualne, upośledzenie narządu ruchu czy niepełnosprawność sensoryczna (dysfunkcje obejmujące wzrok, słuch i mowę).

Inspiracją podczas procesu tworzenia autorskiej Skali Wydolności Opiekuńczej (SWO) (ang. Scale Efficiency of Care; SEC) były badania prowadzone przez Z. Kawczyńską-Butrym wśród rodzin osób przewlekle chorych, u których występowała niepełnosprawność [5]. Zaprezentowana w nich samoocena możliwości i potencjału rodziny ściśle koresponduje z diagnozą wydolności opiekuńczej, jaką można dokonać za pośrednictwem nowatorskiego narzędzia, jakim jest SWO. Podczas konstruowania twierdzeń wchodzących w skład SWO skupiono się na interwencjach opiekuńczo-pielęgnacyjnych podejmowanych przez rodziców oraz zasobach osobistych, z których korzystają w trakcie sprawowania opieki.

Celem niniejszej pracy było zaprezentowanie autorskiego narzędzia badawczego - Skali Wydolności Opiekuńczej (SWO) - oraz określenie jej psychometrycznych właściwości.

Analiza statystyczna wykazała, iż rodzice wychowujący dziecko, u którego występuje niepełnosprawność uzyskali niższe wyniki SWO niż rodzice wychowujący dzieci zdrowe, bez zaburzeń rozwojowych. Wyniki obydwu grup różniły się istotnie $(p<0,05)$, co stwarzało konieczność opracowania odrębnych norm SWO - zarówno dla grupy badanej, jak i porównawczej. Stres znacząco wpływa na stan psychospołeczny rodziców wychowujących dzieci z chorobami przewlekłymi. Liczne badania potwierdzają, iż doświadczają oni silniejszego stresu niż rodzice posiadający zdrowe potomstwo. Poczucie dużej odpowiedzialności za działania lecznicze i usprawniające, jakie podejmowane są u dziecka oraz zmniejszone zdolności podopiecznego w zakresie samoopieki i samopielęgnacji, skłaniają do wygenerowania większej ilości sił w celu zaspokojenia potrzeb opiekuńczo-pielęgnacyjnych. Wymienione wyżej czynniki mogą mieć istotny wpływ na odczuwanie stresu rodzicielskiego, a co za tym idzie efektywność opieki [25].

W celu ułatwienia szczegółowej interpretacji badanej cechy - wydolności opiekuńczej - wykorzystano skalę stenową. Potencjał opiekuńczy został podzielony na trzy poziomy - niski, przeciętny i wysoki - w zależności od liczby punktów uzyskanych przez respondenta. Zabieg ten pozwala na skategoryzowanie cechy, a tym samym może ułatwiać zestawianie i porównywanie między sobą wyników z różnych badań.

Współczynnik Alfa Cronbacha (który wyniósł 0,808 dla grupy rodziców dzieci z niepełnosprawnością oraz 0,791 dla grupy rodziców dzieci zdrowych) potwierdził wewnętrzną spójność opracowanej skali, czyli jej rzetelność. Oznacza to, iż autorskie narzędzie jest jednorodne (homogeniczne), a wszystkie 12 twierdzeń, które wchodzą w jego skład badają tą samą cechę - potencjał opiekuńczy.

Należy zaznaczyć, iż korelacja SWO z GSES - narzędziem o podobnym konstrukcie teoretycznym wskazała na trafność opracowanej skali. Zatem SWO mierzy cechę, do pomiaru której została skonstruowana. Przeprowadzona analiza statystyczna wykazała, iż wyniki SWO i GSES korelują istotnie ze sobą w grupie rodziców wychowujących dzieci zdrowe i grupie rodziców sprawujących opiekę nad dzieckiem z zaburzeniami rozwoju $(p<0,05)$. Według K. M. Benzies i wsp. [26] uogólnione poczucie własnej skuteczności można wykorzystać jako predyktor - czynnik prognozujący dostosowanie rodziny do trudnej sytuacji, jaką jest wychowywanie syna lub córki ze znacznym stopniem niepełnosprawności. Stwierdzono, iż skala GSES stanowi narzędzie o zbliżonym konstrukcie teoretycznym, gdyż ocenia przekonanie o swojej skuteczność, którą można także postrzegać jako efektywność i wydolność w działaniach opiekuńczo-pielęgnacyjnych.

Prezentowane badanie należy poddać analizie w aspekcie jego ograniczeń. Słabą stroną była mała liczebność grupy badanej i kontrolnej oraz brak losowego doboru próby, co uniemożliwia odniesienie i uogólnienie wniosków do całej populacji rodziców wychowujących dzieci z niepełnosprawnością i dzieci zdrowe. Badanie było dobrowolne i anonimowe, uczestniczyli w nim tylko ochotnicy, co wyjaśnia małą liczbę uzyskanych kwestionariuszy. Zaprojektowane badanie miało charakter przekrojowy, należy do badań obserwacyjnych, których moc i wartość naukowa jest słabsza w porównaniu do badań eksperymentalnych lub tych, w których zastosowana jest randomizacja.

Należy zaznaczyć, iż zaprezentowane badanie potwierdza zasadność projektowania i wdrażania nowych rozwiązań, których celem będzie ocena funkcjonalności rodziny w aspekcie opieki i pielęgnacji. Autorska Skala Wydolności Opiekuńczej (SWO) może zostać wykorzystana jako narzędzie w innych badaniach o zbliżonej tematyce, np. w badaniach dotyczących diagnozy sytuacji rodziny dziecka z niepełnosprawnością oraz określeniu rodzajów wsparcia społecznego, jakie potrzebują rodzice (zwłaszcza w początkowych etapach opieki). 
Zaprezentowane normy ułatwiają interpretację wydolności opiekuńczej, którą można definiować jako niską, przeciętną i wysoką. Przeprowadzona analiza statystyczna pozwala twierdzić, iż narzędzie to jest trafne i rzetelne, choć konfirmacyjna analiza czynnikowa (CFA) potwierdziła jej trafność nieco słabiej, jakkolwiek w akceptowalnym stopniu. Zaletą skali jest to, że jest krótka i nie wymaga dużych nakładów czasowych podczas wypełniania. Należy jednak zaznaczyć, iż konieczne są dalsze prace mające na celu doskonalenie liczby i treści twierdzeń nowatorskiej Skali Wydolności Opiekuńczej (SWO). Zasadne wydaje się jej ewentualne rozbudowanie, a z pewnością podział na podskale, co może umożliwić uzyskanie jeszcze bardziej szczegółowej diagnozy potencjału opiekuńczego rodziny.

\section{Wnioski}

1. Opracowana Skala Wydolności Opiekuńczej (SWO) składająca się z twierdzeń dotyczących interwencji opiekuńczo-pielęgnacyjnych, badająca potencjał opiekuńczy rodziców prezentuje zadowalające właściwości psychometryczne: rzetelność - spójność wewnętrzną, potwierdzoną współczynnikami Alfa Cronbacha oraz trafność, dowiedzioną korelacją ze skalą o podobnej koncepcji teoretycznej, i konfirmacyjną analizą czynnikową.

2. Skonstruowane narzędzie może zostać wykorzystane do badania wydolności opiekuńczej rodziców wychowujących dzieci z niepełnosprawnością oraz rodziców wychowujących dzieci zdrowe. Opracowane normy ułatwiają interpretowanie i opisywanie tej zmiennej, pozwalają też zobiektywizować wynik surowy skali.

3. Wskazane są dalsze badania, zwłaszcza dotyczące poszerzenia liczby twierdzeń i wyodrębnienia podskal w SWO oraz eksploracja zagadnienia potencjału opiekuńczego i funkcjonalności rodziny.

\section{Podziękowania}

Autorzy pracy składają serdeczne podziękowania dla wszystkich rodziców, którzy wyrazili chęć uczestniczenia w badaniu, dyrekcji placówek oświatowych za wyrażenie zgody na przeprowadzenie badania oraz Pani dr hab. n. o zdr., dr n. med. Danucie Zarzyckiej za wsparcie merytoryczne i inspirację, która przyczyniła się do powstania niniejszej pracy.

\section{Piśmiennictwo}

1. Constitution of the World Health Organization, (data dostępu: 03.01.2019) http://www.who.int/governance/eb/who_constitution_en.pdf.
2. Witt WP, DeLeire T. A family perspective on population health: the case of children health and the family. WMJ. 2009; 108 (5): 240-245.

3. Tyszka Z. Podstawowe formy małżeństwa, rodziny oraz sieci pokrewieństwa. W: Tyszka Z. (red.). Socjologia rodziny. Wyd. 3. Warszawa: PWN; 1979. 54-89.

4. Witt WP, Riley AW, Coiro MJ. Childhood functional status, family stressors and psychosocial adjustment among shoolaged children with disabilities in the United States. Arch Pediatr Adolesc Med. 2003; 157 (7): 687-695.

5. Kawczyńska-Butrym Z. Rodziny osób niepełnosprawnych. Raport z badań. Warszawa: Wydawnictwo IFiS PAN; 1994.

6. Kawczyńska-Butrym Z. Pomoc dla osób niepełnosprawnych i ich rodzin w środowisku zamieszkania. W: Kawczyńska-Butrym Z. (red.). Niepełnosprawność - specyfika pomocy społecznej. Warszawa: Interart; 1996. 93-117.

7. Hrynkiewicz J. Los starca zależy od kontekstu społecznego - Wprowadzenie. W: Hrynkiewicz J. (red.). O sytuacji ludzi starszych. Tom 3. Warszawa: Rządowa Rada Ludnościowa; 2012. 7-18.

8. Kawczyńska-Butrym Z. Zadania opiekuńcze rodziny. W: Kawczyńska-Butrym Z. (red.). Wyzwania rodziny: zdrowie, choroba, niepełnosprawność, starość. Wyd. 1. Lublin: Wydawnictwo Makmed; 2008. 33-43.

9. Bandura A. Self-efficacy: Toward a unifying theory of behavioral change. Psychol Rev. 1977; 34 (2): 191-215.

10. Bandura A. Self-efficacy mechanism in human agency. Am Psychol. 1982; 37 (2): 122-147.

11. Deklaracja Helsińska (2013), (data dostępu: 05.01.2019). http://www.nil.org.pl/_data/assets/pdf_file/0010/93097/ Deklaracja-Helsinska-przyjeta-na-64-ZO-WMA_pazdziernik-2013_pelny-tekst.pdf.

12. Lenartowicz H, Kózka M. Metodologia badań w pielęgniarstwie. Podręcznik dla studiów medycznych. Wyd. 1. Warszawa: Wydawnictwo Lekarskie PZWL; 2010.

13. Hu LT, Bentler PM. Cutoff criteria for fit indexes in covariance structure analysis: Conventional criteria versus new alternatives. Structural Equation Modeling: A Multidisciplinary Journal. 1999; 6 (1): 1-55.

14. R 3.2.3. R Development Core Team (2009). R: A language and environment for statistical computing. R Foundation for Statistical Computing, Vienna, Austria. ISBN 3-90005107-0, http://www.R-project.org (data dostępu: 05.01.2019).

15. Likert R. A technique for the measurement of attitudes. New York: The Science Press; 1932, http://www.voteview.com/ pdf/Likert_1932.pdf (data dostępu: 05.01.2019).

16. Nawalana A, Kózka M, Majda A. Determinants of care efficiency in a group of Polish parents raising children with different developmental disorders: a cross-sectional study. Int J Dev Disabil. Published online 15.01.2019 doi:

17. Juczyński Z. Narzędzia pomiaru w promocji i psychologii zdrowia. Warszawa: Pracownia Testów Psychologicznych Polskiego Towarzystwa Psychologicznego; 2001.

18. Twardowski A. Sytuacja rodzin dzieci niepełnosprawnych. W: Obuchowska I. (red.). Dziecko niepełnosprawne w rodzinie. Wyd. 3. Warszawa: Wydawnictwo Szkolne i Pedagogiczne Spółka Akcyjna; 1999. 18-54.

19. Bakiera L, Stelter Ż. Rodzicielstwo z perspektywy rodziców dziecka pełnosprawnego i niepełnosprawnego intelektualnie. Roczniki Socjologii Rodziny. Zalety i wady życia w rodzinie i poza rodzina. 2010; 20: 131-151.

20. Schulz R, Visintainer P, Williamson GM. Psychiatric and physical morbidity effects of caregiving. J Gerontol. 1990; 45 (5): 181-191. 
21. Thomas SV, Bindu VB. Psychosocial and economic problems of parents of children with epilepsy. Seizure. 1999; 8 (1): 66-69.

22. Szweda-Lewandowska Z. Wyzwania związane z starzeniem się ludności w zakresie pomocy instytucjonalnej w Łodzi. Acta Universitatis Lodziensis. Folia Sociologica. 2010, 35: 127-142.

23. Błachnio A. Starość w rodzinie. Opieka nad seniorem wyzwaniem dla dorosłego dziecka czy państwa? Wychowanie w Rodzinie. 2016; 13 (1): 441-453.

24. Misiak K. Zadania pielęgniarki podstawowej opieki zdrowotnej w ujęciu gerontologicznym. Piel. Zdr. Publ. 2011, 1 (4): 359-366.

25. Cousino MK, Hazen RA. Parenting stress among caregivers of children with chronic illness: a systematic review. J Pediatr Psychol. 2013; 38 (8): 809-828.

26. Benzies KM, Trute B, Worthington $C$. Maternal self-efficacy and family adjustment in households with children with serious disability. J Fam Stud. 2014; 19 (1): 35-43.
Artykuł przyjęty do redakcji: 21.01.2019.

Artykuł przyjęty do publikacji: 26.07.2019.

Źródło finansowania: Badanie było finansowane ze środków pochodzących z dotacji celowej dla młodych naukowców oraz uczestników studiów doktoranckich do 35. roku życia (numer: K/DSC/002876).

Konflikt interesów: Autorzy deklarują brak konfliktu interesów.

Adres do korespondencji:

Anna Kurowska

ul. Michałowskiego 12

31-126 Kraków

tel. 126343397 wew. 19

e-mail: anna2.kurowska@uj.edu.pl

Pracownia Teorii i Podstaw Pielęgniarstwa, Wydział Nauk o Zdrowiu Uniwersytetu Jagiellońskiego Collegium Medicum w Krakowie 